\title{
Characterization and Pathogenicity of Botryosphaeriaceae Species Collected from Olive and Other Hosts in Spain and California
}

\author{
Juan Moral, Concepción Muñoz-Díez, Nazaret González, Antonio Trapero, and Themis J. Michailides
}

First, second, third, and fourth authors: Departamento de Agronomía, ETSIAM, Universidad de Córdoba, Campus de Rabanales, Edif. C4, 14071 Córdoba, Spain; and fifth author: Department of Plant Pathology, University of California-Davis, Kearney Agricultural Center, 9240 South Riverbend Ave., Parlier 93648.

Accepted for publication 19 August 2010.

\begin{abstract}
Moral, J., Muñoz-Díez, C., González, N., Trapero, A., and Michailides, T. J. 2010. Characterization and pathogenicity of Botryosphaeriaceae species collected from olive and other hosts in Spain and California. Phytopathology 100:1340-1351.

Species in the family Botryosphaeriaceae are common pathogens causing fruit rot and dieback of many woody plants. In this study, 150 Botryosphaeriaceae isolates were collected from olive and other hosts in Spain and California. Representative isolates of each type were characterized based on morphological features and comparisons of DNA sequence data of three regions: internal transcribed spacer $5.8 \mathrm{~S}, \beta$ tubulin, and elongation factor. Three main species were identified as Neofusicoccum mediterraneum, causing dieback of branches of olive and pistachio; Diplodia seriata, causing decay of ripe fruit and dieback of olive branches; and Botryosphaeria dothidea, causing dalmatian disease on unripe olive fruit in Spain. Moreover, the sexual stage of this last species was also found attacking olive branches in California. In patho-

genicity tests using unripe fruit and branches of olive, D. seriata isolates were the least aggressive on the fruit and branches while $N$. mediterraneum isolates were the most aggressive on both tissues. Isolates of $B$. dothidea which cause dalmatian disease on fruit were not pathogenic on branches and only weakly aggressive on fruit. These results, together with the close association between the presence of dalmatian disease symptoms and the wound created by the olive fly (Bactrocera oleae), suggest that the fly is essential for the initiation of the disease on fruit. Isolates recovered from dalmatian disease symptoms had an optimum of $26^{\circ} \mathrm{C}$ for mycelial growth and $30^{\circ} \mathrm{C}$ for conidial germination, suggesting that the pathogen is well adapted to high summer temperatures. In contrast, the range of water activity in the medium for growth of dalmatian isolates was 0.93 to $1 \mathrm{MPa}$, which was similar to that for the majority of fungi. This study resolved long-standing questions of identity and pathogenicity of species within the family Botryosphaeriaceae attacking olive trees in Spain and California.
\end{abstract}

The Spanish olive (Olea europaea L.) industry (both table and oil) presently occupies $>2,476,540$ ha, producing an annual crop valued at $>\$ 3.6$ billion (26), and represents $>42 \%$ of world production (13). California produces an average of $\approx 110,000$ tons of olive fruit on 13,760 ha, most of which is table fruit (49). Most of the olive fruit diseases, caused by pathogens such as Colletotrichum spp., Phlyctema vagabunda, Fusarium spp., or Alternaria alternata, affect the ripening fruit during the autumn to winter $(4,10,29)$. However, because the fruit is collected before ripening, these diseases are not important to the olive table fruit industry. In contrast, because Botryosphaeria dothidea (Moug.) Ces. \& De Not., causal agent of dalmatian disease of olive fruit, is able to affect unripe fruit, it is considered the most important fruit disease of table fruit. This fungus can infect fruit during the summer with high temperatures and low relative humidity $(4,16)$. However, details on the influence of the environment and host are unclear.

Dalmatian disease was first described in 1883 on olive fruit from Dalmatia, Croatia (47). Today, the disease is widespread around the Mediterranean basin $(4,18,53)$. The name of the disease in Spanish and Portuguese is "escudete" (small shield) due to the pathogen producing a sunken, necrotic, and elliptical or circular $(\approx 8-\mathrm{mm}$ diameter) lesion with a sharp edge delineating

Corresponding authors: A. Trapero; E-mail address: trapero@uco.es and

T. J. Michailides; E-mail address: themis@uckac.edu

* The $\boldsymbol{e}$-Xtra logo stands for "electronic extra" and indicates that the online version contains four supplemental figures.

doi:10.1094/PHYTO-12-09-0343

(C) 2010 The American Phytopathological Society infected and healthy tissues $(4,16,27)$. Fruit with this symptom cannot be marketed as table olive fruit, resulting in significant economic loss. During the winter, when fruit are ripe, infected fruit drop to the ground and are mummified, although the original shield ("escudete") lesion remains visible $(4,16,27,53)$.

Since the time of the original description, the fungus causing dalmatian disease, originally described as Phyllosticta dalmatica Thüm., has undergone several taxonomic changes because of the presence of conidia with different morphologies and the absence of the sexual stage. The pathogen causing dalmatian disease has been identified as Phoma dalmatica (Thüm.) Sacc., Macrophoma dalmatica (Thüm) Berl. \& Voglino, and Sphaeropsis dalmatica (Thüm.) Gigante (4,33). Zachos and Tzavella-Klonari (53) studied the morphological characteristics of conidia produced by the dalmatian disease fungus and reported that the fungus produced two kinds of conidia. The most common conidia were Fusicoccum-like and the second type were light brown and ovoid or ellipsoid, with 0 to 5 transversal or 0 to 3 longitudinal septa. As a result, this second kind of conidia led to the pathogen being described as Camarosporium dalmaticum (Thüm.) Zachos \& Tzav.-Klon. Later, the fungus causing dalmatian disease was reclassified as Fusicoccum dalmaticum (Thüm.) Vanev (1). Currently, based on isolates from Italy and Greece, the pathogen has been classified as $F$. aesculi Corda, which is the anamorph of $B$. dothidea $(22,33)$. However, these authors did not specify the kind of symptoms produced by this fungus on infected olive fruit. In Spain, this pathogen has been hardly studied $(4,16,27)$.

Recently, Crous et al. (9) showed that the genus Botryosphaeria is composed of 10 lineages, which correspond to individual genera. Only B. dothidea and B. corticis (Demaree \& Wilcox) Arx 
\& E. Müll. were retained in the original genus Botryosphaeria and its anamorphs in the genus Fusicoccum. In contrast, other "Botryosphaeria" spp. with Fusicoccum-like anamorphs or Dichomera-like synanamorphs were transferred to the new anamorph genus Neofusicoccum Crous, Slippers, \& A. J. L. Phillips. Therefore, the genus Botryosphaeria is no longer used for species other than B. dothidea and B. corticis. Consequently, in these cases, the genus "Botryosphaeria" is written in quotes because the anamorph names should be used in preference $(9,43)$.

As with many perennials, olive trees are affected by a number of species of Botryosphaeriaceae $(5,28,41-44,48)$. In Spain, B. dothidea causes typical dalmatian disease on fruit $(4,16,22)$; Neofusicoccum ribis (Slippers, Crous \& M. J. Wingf.) Crous, Slippers \& A. J. L. Phillips (teleomorph: "B". ribis Grossenb. \& Duggar) causes branch dieback only on the cv. Gordal Sevillana, which is considered the most important table olive cultivar $(4,37)$; and Diplodia seriata De Not. (teleomorph: " $B$ ". obtusa (Schwein.) Shoemaker) causes diplodia rot of ripe fruit (31). This apparent pathogenic specialization between species of Botryosphaeriaceae and specific olive tissue has not been studied.

In California in the early 1970s, growers reported twig dieback to be common on olive trees. A Diplodia sp. was isolated consistently from these small branches. The same fungus was also isolated from sunburned areas, dead portions of trees infected with Verticillium dahliae, olive knot galls, and branch cankers (40). After colonizing olive knot galls (caused by Pseudomonas savastanoi pv. savastanoi), the Diplodia sp. advanced into the twig to form an elliptical canker (46). Moreover, pseudothecia (ascocarps) of $B$. dothidea were found on blighted olive shoots (28). In these studies, identification of Botryosphaeriaceae species was based on morphological characteristics $(28,30,37)$. However, some closely related species are difficult to tell apart based on anamorph morphology $(6,7,9,19,48)$. Characters of neither the teleomorph nor the anamorph are reliable for definitive identification of some Botryosphaeriaceae species with Fusicoccumpycnidiospores. Thus, multiallelic DNA sequence data are being used to identify Botryosphaeriaceae species from various hosts $(20,22,41-43,48)$.

Because no detailed studies were made of the identity and pathogenicity of the Botryosphaeriaceae species from olive and other hosts growing in the proximity of olive groves, the objectives of the present study were to (i) identify the Botryosphaeriaceae species attacking olive in Spain and California, using morphological characteristics and molecular techniques; (ii) study the potential pathogenic specialization of these species on olive tissues; and (iii) evaluate the effects of some environmental and host conditions, such as temperature, water potential, cultivar, and presence or absence of wounds in the fruit on disease development. This information is essential to develop successful disease management strategies. A preliminary report has already been published (31).

\section{MATERIALS AND METHODS}

Collections of fungal isolates. From 2002 to 2008, olive fruit with symptoms typical of dalmatian disease or diplodia fruit rot, and blighted shoots from olive, pistachio (Pistacia vera), quince (Cydonia oblonga), strawberry tree (Arbutus unedo), and walnut (Juglans regia) were collected in Spain (southern Andalusia and northeastern Catalonia regions). Quince fruit with black rot symptoms from Andalusia were also collected. Additionally, blighted or dead shoots from olive, pistachio, and ash (Fraxinus sp.) trees were collected in California (Table 1). Affected shoots of the different hosts were surface disinfested with a $70 \%$ ( $\mathrm{vol} / \mathrm{vol})$ ethanol solution or household bleach $\left(\mathrm{Cl}\right.$ at $\left.50 \mathrm{~g} \mathrm{liter}^{-1}\right)$ at $20 \%(\mathrm{vol} / \mathrm{vol})$ in sterile water for $1 \mathrm{~min}$. Bark tissues ( 3 to 4 by 3 by 1 to $2 \mathrm{~mm}$ ) were cut with a sterile scalpel and placed in petri dishes containing potato dextrose agar (PDA) (Difco Labora- tories, Detroit) acidified with lactic acid (2.5 $\mathrm{ml}$ of $25 \%$ [vol/vol] per liter of medium) to minimize bacterial growth (APDA). When the affected tissues were fruit, fruiting structures (pycnidia) were removed using a sterile needle and cultured in petri dishes on APDA. Petri dishes were incubated at $23 \pm 2{ }^{\circ} \mathrm{C}$ under a 12-h diurnal photoperiod of cool fluorescent light $\left(350 \mu \mathrm{mol} \mathrm{m} \mathrm{m}^{-2} \mathrm{~s}^{-1}\right)$ until fungal colonies were large enough to be examined. To obtain pure cultures, hyphal tips from the colonies of the Botryosphaeriaceae species were transferred to fresh APDA and incubated as described above. In total, 150 Botryosphaeriaceae isolates were obtained and divided into six different groups according to colony morphology. Representing all these groups, 55 isolates were selected for this study (Table 1). These isolates are maintained in the collections of the Department of Plant Pathology at the University of California-Davis (Kearney Agricultural Center in Parlier) and the Departamento de Agronomía, Universidad de Córdoba in Spain.

Morphological characterization. Because morphological characteristics are still used partially to characterize species of Botryosphaeriaceae, all 55 Botryosphaeriaceae isolates from these six different groups were studied morphologically (Table 1). Color (using a color scale) (20), growth, and presence or absence of conidiomata from these isolates were recorded at 7 and 14 days of growth of the colonies after incubation on PDA at $23 \pm 2^{\circ} \mathrm{C}$ with a 12-h diurnal photoperiod of cool fluorescent light $\left(350 \mu \mathrm{mol} \mathrm{m} \mathrm{m}^{-2} \mathrm{~s}^{-1}\right)$. To study the formation of pycnidia, the same isolates were cultured on sterile olive (cv. Gordal Sevillana) and pistachio (cv. Kerman) leaves. Leaves were autoclaved at $120^{\circ} \mathrm{C}$ for $20 \mathrm{~min}$ and then placed into petri dishes containing $5 \mathrm{ml}$ of molten PDA, which acted as an adhesive. Petri dishes were incubated as described above for 10 days. Three petri dishes per isolate and medium were used and the experiment was performed twice.

The length and width of 50 conidia per isolate were measured at a magnification of $\times 1,000$ with the aid of a compound microscope (Nikon Eclipse 80i; Nikon Corp., Tokyo). The conidia extracted from pycnidia in PDA and pistachio or olive leaves were not significantly different (Tukey's honestly significant difference [HSD] test; $P=0.463$ ); therefore, either were used for conidium measurement studies, providing minimum size, maximum size, and $95 \%$ confidence limits. Conidial color, shape, and septation were also recorded. In addition, pycnidia and conidia of two isolates (BOO052 and BOO053) were directly measured from olive fruit with symptoms of dalmatian disease in the field. Data from all experiments were analyzed using Statistix 9 (Analytical Software, Tallahassee, FL).

Molecular characterization. Because morphological features are not solely sufficient for the speciation of the Botryosphaeriaceae members, DNA sequences of internal transcribed spacer (ITS)-5.8S, $\beta$-tubulin (BT), and elongation factor (EF) were also determined in order to fully characterize the isolates. Total genomic DNA from Botryosphaeriaceae isolates was extracted from pure culture mycelia using a FastDNA Kit (BIO 101, Inc., Vista, CA). The nuclear ribosomal DNA repeats, including ITS1, 5.8S rRNA, ITS2, and portions of the genes encoding both small and large subunit rRNAs, were amplified using primers ITS1 and ITS4 (50). Oligonucleotide primers $\mathrm{Bt} 2 \mathrm{a}$ and $\mathrm{Bt} 2 \mathrm{~b}$ were used to amplify a portion of the BT gene (15). Amplification of part of the translation EF gene was done with the primers EF1-728F and EF1-986R (7). The polymerase chain reaction (PCR) of ITS, BT, and EF were carried out according to previous studies $(22,48)$. The PCR products were purified using an Ultra Clean PCR Clean-Up Kit (MO BIO Laboratories, Inc., Solana Beach, CA). The resulting amplicons were sequenced in both directions using an automated sequencer by the Division of Biological Sciences sequencing facility, University of California-Davis. The nucleotide sequences were read and edited with FinchTV 1.4.0. Sequences of the strains isolated in this study were compared with 
those of Botryosphaeriaceae species from previous studies available in the National Center for Biotechnolgoy Information database GenBank (Table 2). The ITS, BT, and EF sequences of 55 Botryosphaeriaceae species from different hosts from Spain and California were aligned with 23 GenBank sequences of the same genes of Botryosphaeriaceae species. The sequences were aligned using the computer program MEGA version 4.0 (45) and alignment gaps were treated as missing data. Before the phylogenetic analysis, data sets including only the different haplotypes of each alignment and the invariable sites and gaps were generated using DNASp v5.10 (38).

A partition homogeneity test was performed with PAUP v.4.0b10 (51) to determine whether the ITS, BT, and EF data sets could be combined together. Separate phylogenetic analyses were also performed for the ITS data set alone, BT data set alone, and $\mathrm{EF}$ data set alone, and tree topologies were compared. To obtain

TABLE 1. Isolates of Botryosphaeria dothidea, Diplodia seriata, Neofusicoccum mediterraneum, and N. parvum from Spain and California used in this study

\begin{tabular}{|c|c|c|c|c|c|c|c|c|}
\hline \multirow[b]{2}{*}{ Species $^{\mathrm{V}}$} & \multirow[b]{2}{*}{ Isolates $^{\mathrm{w}}$} & \multirow[b]{2}{*}{ Host, cultivar } & \multirow[b]{2}{*}{ Origin $^{\mathrm{x}}$} & \multirow[b]{2}{*}{ Date collected } & \multirow[b]{2}{*}{ Symptoms $^{\mathrm{y}}$} & \multicolumn{3}{|c|}{ GenBank accession no. ${ }^{\mathrm{z}}$} \\
\hline & & & & & & ITS & $\beta$-Tubulin & $\mathrm{EF} 1-\alpha$ \\
\hline & & Olea eur & & & & & & \\
\hline B. dothidea & BOO046 & 'Santa Caterina' & Mengíbar, An & October 06 & Dalmatian disease & GU292626 & GU292738 & GU292682 \\
\hline B. dothidea & BOO047 & 'Santa Caterina' & Mengíbar, An & October 06 & Dalmatian disease & GU292627 & GU292739 & GU292683 \\
\hline B. dothidea & BOO049 & 'Gordal Sevillana' & Cabra, An & November 06 & Mummified fruit & GU292628 & GU292740 & GU292684 \\
\hline B. dothidea & BOO050 & 'Gordal Sevillana' & Cabra, An & November 06 & Dalmatian disease & GU292629 & GU292741 & GU292685 \\
\hline B. dothidea & BOO051 & 'Manzanillo de Córdoba' & Córdoba, An & November 06 & Dalmatian disease & GU292630 & GU292742 & GU292686 \\
\hline B. dothidea & BOO052 & 'Manzanillo de Córdoba' & Córdoba, An & November 06 & Dalmatian disease & GU292631 & GU292743 & GU292687 \\
\hline B. dothidea & BOO053 & 'Manzanilla de Sevilla' & Córdoba, An & November 06 & Dalmatian disease & GU292632 & GU292744 & GU292688 \\
\hline B. dothidea & BOO054 & 'Manzanilla de Sevilla' & Córdoba, An & November 06 & Dalmatian disease & GU292633 & GU292745 & GU292689 \\
\hline B. dothidea & BOO055 & 'Manzanilla de Sevilla' & Mengíbar, An & December 07 & Dalmatian disease & GU292634 & GU292746 & GU292690 \\
\hline B. dothidea & BOO056 & 'Manzanilla de Sevilla' & Mengíbar, An & December 07 & Dalmatian disease & GU292635 & GU292747 & GU292691 \\
\hline B. dothidea & BOO074 & O. europaea & Villanueva, An & June 05 & Dalmatian disease & GU292648 & GU292760 & GU292704 \\
\hline B. dothidea & BOO075 & O. europaea & Villanueva, An & June 05 & Dalmatian disease & GU292649 & GU292761 & GU292705 \\
\hline B. dothidea & BOO076 & O. europaea & El Saucejo, An & June 05 & Dalmatian disease & GU292650 & GU292762 & GU292706 \\
\hline B. dothidea & BOO077 & O. europaea & El Saucejo, An & June 05 & Dalmatian disease & GU292651 & GU292763 & GU292707 \\
\hline B. dothidea & BOO078 & O. europaea & El Saucejo, An & June 05 & Dalmatian disease & GU292652 & GU292764 & GU292708 \\
\hline B. dothidea & BOO079 & O. europaea & Villanueva, An & June 05 & Dalmatian disease & GU292653 & GU292765 & GU292709 \\
\hline B. dothidea & BOO080 & O. europaea & Sierra Norte, An & June 05 & Dalmatian disease & GU292654 & GU292766 & GU292710 \\
\hline B. dothidea & BOO086 & O. europaea & Sierra Norte, An & June 05 & Dalmatian disease & GU292655 & GU292767 & GU292711 \\
\hline B. dothidea & BOO089 & O. europaea & Sierra Norte, An & June 05 & Dalmatian disease & GU292656 & GU292768 & GU292712 \\
\hline B. dothidea & BOO092 & O. europaea & Sierra Norte, An & July 05 & Dalmatian disease & GU292657 & GU292769 & GU292713 \\
\hline B. dothidea & BOO097* & O. europaea & Glenn, CA & June 05 & Branch canker & GU292660 & GU292772 & GU292716 \\
\hline B. dothidea & BOO098* & O. europaea & Glenn, CA & June & Branch canker & GU292661 & GU292773 & GU292717 \\
\hline B. dothidea & BOO100* & O. europaea & Glenn, CA & June 05 & Branch canker & GU292662 & GU292774 & GU292718 \\
\hline B. dothidea & BOO104* & O. europaea & Glenn, CA & & Blighted shoot & GU292665 & GU292777 & GU292721 \\
\hline B. dothidea & BOO105* & O. europaea & Glenn, CA & June 05 & Blighted shoot & GU292666 & GU292778 & GU292722 \\
\hline B. dothidea & BOA177 & Arbutus unedo & Córdoba, An & September 08 & Blighted shoot & GU292677 & GU292789 & GU292733 \\
\hline D. seriata & BOM037 & Cydonia oblonga 'Común' & Carcabuey, An & October 06 & Black fruit rot & GU292625 & GU292737 & GU292681 \\
\hline D. seriata & BOO059 & O. europaea 'Hojiblanca' & La Rambla, An & November 06 & Asymptomatic fruit & GU292636 & GU292748 & GU292692 \\
\hline D. seriata & BOO060 & O. europaea 'Hojiblanca' & La Rambla, An & November 06 & Infection on fruit* & GU292637 & GU292749 & GU292693 \\
\hline D. seriata & BO0061 & O. europaea 'Hojiblanca' & La Rambla, An & November 06 & Infection on fruit* & GU292638 & GU292750 & GU292694 \\
\hline D. seriata & BOO062 & O. europaea 'Hojiblanca' & La Rambla, An & November 06 & Infection on fruit* & GU292639 & GU292751 & GU292695 \\
\hline D. seriata & BO0096 & O. europaea & Madera, CA & June 05 & Blighted shoot & GU292659 & GU292771 & GU292715 \\
\hline D. seriata & BOO107 & O. europaea & Madera, CA & July 03 & Blighted shoot & GU292667 & GU292779 & GU292723 \\
\hline D. seriata & BOPKAC & $\begin{array}{l}\text { Pistacia vera 'Kerman' } \\
\text { O. europaea }\end{array}$ & California & June 02 & Blighted shoot & GU292680 & GU292792 & GU292736 \\
\hline N. mediterraneum & BO0068 & 'Gordal Sevillana' & al, An & & & GU292642 & GU292754 & GU292698 \\
\hline N. mediterraneum & BO0069 & 'Gordal Sevillana' & Arahal, An & September 02 & Blighted shoot & GU292643 & GU292755 & GU292699 \\
\hline N. mediterraneum & BOO070 & 'Gordal Sevillana' & Arahal, An & September 02 & Blighted shoot & GU292644 & GU292756 & GU292700 \\
\hline N. mediterraneum & BOO071 & 'Gordal Sevillana' & Arahal, An & September 02 & Blighted shoot & GU292645 & GU292757 & GU292701 \\
\hline N. mediterraneum & BOO072 & 'Gordal Sevillana' & Arahal, An & September 02 & Blighted shoot & GU292646 & GU292758 & GU292702 \\
\hline N. mediterraneum & BOO073 & 'Gordal Sevillana' & Sevilla, An & March 02 & Blighted shoot & GU292647 & GU292759 & GU292703 \\
\hline N. mediterraneum & BOO102 & O. europaea & California & June 05 & Blighted shoot & GU292663 & GU292775 & GU292719 \\
\hline N. mediterraneum & BOO103 & O. europaea & California & June 05 & Blighted shoot & GU292664 & GU292776 & GU292720 \\
\hline N. mediterraneum & BOF115 & Fraxinus sp. & Mendota, CA & July 06 & Blighted shoot & GU292668 & GU292780 & GU292724 \\
\hline N. mediterraneum & BOF116 & Fraxinus sp. & Mendota, CA & July 06 & Blighted shoot & GU292669 & GU292781 & GU292725 \\
\hline N. mediterraneum & BOO140 & O. europaea & Fresno, CA & May 08 & Blighted shoot & GU292670 & GU292782 & GU292726 \\
\hline N. mediterraneum & BOO142 & O. europaea & Fresno, CA & May 08 & Blighted shoot & GU292671 & GU292783 & GU292727 \\
\hline N. mediterraneum & BOP156 & P. vera 'Keman' & Puente Genil, An & October 07 & Blighted shoot & GU292672 & GU292784 & GU292728 \\
\hline N. mediterraneum & BOP162 & P. vera 'Keman' & Puente Genil, An & October 07 & Infected rachis & GU292673 & GU292785 & GU292729 \\
\hline N. mediterraneum & BOP170 & P. vera 'Keman' & Parlier, CA & October 02 & Infection on fruit* & GU292674 & GU292786 & GU292730 \\
\hline N. mediterraneum & BOP200 & P. vera 'Keman' & California & June 02 & Blighted panicle & GU292678 & GU292790 & GU292734 \\
\hline N. mediterraneum & BOP757 & P. vera 'Keman' & California & June 02 & Blighted panicle & GU292679 & GU292791 & GU292735 \\
\hline N. parvum & BON065 & Juglans regia 'Vina' & Gerona, $\mathrm{Ct}$ & March 07 & Blighted shoot & GU292640 & GU292752 & GU292696 \\
\hline N. parvum & BON066 & J. regia 'Vina' & Gerona, $\mathrm{Ct}$ & March 07 & Blighted shoot & GU292641 & GU292753 & GU292697 \\
\hline N. parvum & BON172 & J. regia 'Hartley' & Badajoz, Ex & September 08 & Blight shoot & GU292675 & GU292787 & GU292731 \\
\hline N. parvum & BON173 & J. regia 'Hartley' & Badajoz, Ex & September 08 & Blight shoot & GU292676 & GU292788 & GU292732 \\
\hline
\end{tabular}

${ }^{\mathrm{v}}$ Botryosphaeriaceae isolates were identified by morphology and phylogenetic analyses.

${ }^{\mathrm{w}}$ An asterisk $\left(^{*}\right)$ indicates isolates that formed the teleomorph under field conditions.

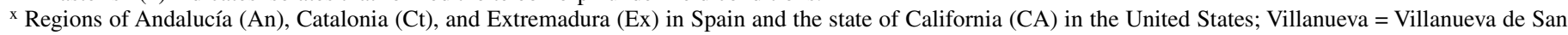
Juan, Sierra Norte $=$ Sierra Norte de Sevilla.

y Asterisk indicates latent infection on fruit.

z ITS = internal transcribed spacer and EF1- $\alpha=$ elongation factor $1-\alpha$. 
appropriate substitution models for maximum likelihood (ML) analysis (11), each alignment was analyzed with jModelTest 0.1.1 (34) using the Akaike information criterion (AIC) (35). Under the respective models found, searches for the best ML tree as well as 1,000 bootstrap replications (12) were done with the fast likelihood software PHYML 3.0, using identical settings.

To determine possible groups of isolates, using PAUP*, a heuristic search under the maximum parsimony (MP) (51) criterion was performed as described (22). The robustness of the most parsimonious trees was evaluated by 1,000 bootstrap replications (12). A phylogenetic tree combining ITS, BT, and EF data sets was made in order to identify the Botryosphaeriaceae isolates sequenced in this study. This tree was rooted to a Bionectria sp. which is closely related to the Botryosphaeriaceae family. Morphological data were not included in the analysis. Due to the absence of previous BT sequences of Botryosphaeriaceae isolates from olive in GenBank, another phylogenetic tree combining exclusively ITS and EF data sets from these isolates was constructed to evaluate the genetic diversity among the olive isolates, as described above.

Pathogenicity tests. To determine whether there is any pathogenic specialization of Botryosphaeriaceae species and the effects of host tissues and inoculation conditions on the infection process, olive branches and fruit were inoculated in the following four experiments:

Effects of cultivar, wounding, and inoculation method. Unripe healthy fruit of two table olive cultivars (Manzanilla de Sevilla and Hojiblanca) were collected in Córdoba province in the Andalusia region during September 2006. Fruit were washed with water and disinfested with commercial bleach following a procedure of Moral et al. (29). Three different factors were studied in this experiment: cultivar, wounding (wounded $[2 \mathrm{~mm}$ deep by

TABLE 2. Sequences of Botryosphaeria, Dichomera, Diplodia, Lasiodiplodia, and Neofusicoccum spp. from GenBank used in the phylogenetic analysis

\begin{tabular}{|c|c|c|c|c|c|c|c|}
\hline \multirow[b]{2}{*}{ Species } & \multirow[b]{2}{*}{ Isolate $y$} & \multirow[b]{2}{*}{ Host } & \multirow[b]{2}{*}{ Origin } & \multirow[b]{2}{*}{ Collector } & \multicolumn{3}{|c|}{ GenBank accession no. ${ }^{\mathrm{z}}$} \\
\hline & & & & & ITS & $\mathrm{EF}$ & $\beta$-Tubulin \\
\hline Bionectria sp. & CMW7063 & Taxus baccata & Netherlands & Van der Aa & AY236956 & AY236905 & AY236934 \\
\hline Botryosphaeria corticis & ATCC22927 & Vaccinium sp. & North Carolina & R. D. Millholland & DQ 299247 & EF614931 & EU673108 \\
\hline B. dothidea & CAP232 & Olea europaea & Sicilia, Italy & C. Lazzizera & EF638747 & EF638727 & $\mathrm{n} / \mathrm{a}$ \\
\hline B. dothidea & CAP233 & O. еuropaea & Sicilia, Italy & C. Lazzizera & EF638748 & EF638728 & $\mathrm{n} / \mathrm{a}$ \\
\hline B. dothidea & CAP238 & O. europaea & Puglia, Italy & C. Lazzizera & EF638760 & EF638729 & $\mathrm{n} / \mathrm{a}$ \\
\hline B. dothidea & CBS116741 & O. europaea & Thessalia, Greece & I. Rumbos & AY640254 & AY640257 & $\mathrm{n} / \mathrm{a}$ \\
\hline B. dothidea & CBS116742 & O. europaea & Thessalia, Greece & I. Rumbos & AY786321 & AY786318 & $\mathrm{n} / \mathrm{a}$ \\
\hline B. dothidea & CBS116743 & O. europaea & Thessalia, Greece & I. Rumbos & AY786322 & AY786319 & $\mathrm{n} / \mathrm{a}$ \\
\hline B. dothidea & CBS116777 & O. europaea & Thessalia, Greece & I. Rumbos & AY786320 & AY786317 & $\mathrm{n} / \mathrm{a}$ \\
\hline B. dothidea & CMW8000 & Prunus sp. & Switzerland & B. Slippers & AY236949 & AY236927 & AY236898 \\
\hline B. dothidea & MUCC503 & Eucalyptus gomphocephala & Australia & K. Taylor & EF591918 & EF591970 & EF591953 \\
\hline D. mutila & CBS230.30 & Phoenix dactylifera & California & L. L. Huillier & DQ458886 & DQ458869 & DQ458849 \\
\hline D. seriata & CBS112555 & $V$. vinifera & Portugal & A. J. L. Phillips & AY259094 & AY573220 & $\mathrm{n} / \mathrm{a}$ \\
\hline D. seriata & CBS119049 & Vitis sp. & Italy & A. J. L. Phillips & DQ458889 & DQ458874 & DQ458857 \\
\hline Lasiodiplodia theobromae & CMW9074 & Pinus sp. & Mexico & B. Slippers & AY236952 & AY236930 & AY236901 \\
\hline L. theobromae & CMW10130 & $V$. vinifera & Uganda & J. Roux & AY236951 & AY236929 & AY236900 \\
\hline Neofusicoccum australe & CMW9072 & Acacia sp. & Australia & T. Burgess/K.-L. Goei & AY339260 & AY339252 & AY339268 \\
\hline N. australe & MUCC496 & E. gomphocephala & Australia & K. Taylor & EF591911 & EF591964 & EF591947 \\
\hline N. australe & CAP226 & O. europaea & Puglia, Italy & C. Lazzizera & EF638774 & EF638737 & $\mathrm{n} / \mathrm{a}$ \\
\hline N. australe & CMW15951 & E. diversicolor & Australia & T. Burgess/K.-L. Goei & DQ093231 & DQ093212 & DQ093225 \\
\hline N. eucalypticola & CMW6539 & E. grandis & Australia & M. J. Wingfield & AY615141 & AY615125 & AY615133 \\
\hline N. eucalypticola & CMW6217 & E. rossii & Australia & M. J. Wingfield & AY615143 & AY615135 & AY615127 \\
\hline N. eucalyptorum & CMW10125 & E. grandis & South Africa & H. Smith & AF283686 & AY236920 & AY236891 \\
\hline N. eucalyptorum & CMW10126 & E. grandis & South Africa & H. Smith & AF283687 & AY236892 & AY236921 \\
\hline$N$. luteum & CMW9076 & Malus $\times$ domestica & New Zealand & S. R. Pennycook & AY339257 & AY339265 & $\mathrm{n} / \mathrm{a}$ \\
\hline N. ribis & MUCC227 & Eucalyptus sp. & Australia & T. I. Burguess & EU301030 & EU339509 & EU339472 \\
\hline N. viticlavatum & STE-U5041 & $V$. vinifera & South Africa & F. Hallen & AY343380 & AY343341 & $\mathrm{n} / \mathrm{a}$ \\
\hline N. viticlavatum & STE-U5044 & $V$. vinifera & South Africa & F. Hallen & AY343381 & AY343342 & $\mathrm{n} / \mathrm{a}$ \\
\hline N. vitifusiforme & CAP201 & O. europaea & Basilicata, Italy & C. Lazzizera & EF638779 & EF638742 & $\mathrm{n} / \mathrm{a}$ \\
\hline N. vitifusiforme & CAP210 & O. europaea & Puglia, Italy & C. Lazzizera & EF638781 & EF638743 & $\mathrm{n} / \mathrm{a}$ \\
\hline N. vitifusiforme & CAP227 & O. europaea & Puglia, Italy & C. Lazzizera & EF638785 & EF638744 & $\mathrm{n} / \mathrm{a}$ \\
\hline
\end{tabular}

${ }^{y}$ Acronyms of culture collections: ATCC $=$ American Type Culture Collection, Fairfax, VA; CAA = Universidade de Aveiro, Portugal; CAP = Universidade Nova de Lisboa, Portugal; CBS = Centraalbureau voor Schimmelcultures, Utrecht, The Netherlands; CMW = FABI, University of Pretoria, South Africa; MUCC = Lab. of Plant Pathology, Mie University, Japan; STE-U = University of Stellenbosch, South Africa.

${ }^{\mathrm{z}} \mathrm{ITS}=$ internal transcribed spacer, $\mathrm{EF}=$ elongation factor, and $\mathrm{n} / \mathrm{a}=$ not available at the time of this publication. 
$0.8 \mathrm{~mm}$ wide] or unwounded fruit), and two inoculation methods (using a 10-mm mycelium PDA plug from a 1-week-old culture or $10 \mu \mathrm{l}$ of a suspension of $1.2 \times 10^{6}$ conidia per $\mathrm{ml}$ ). One isolate (BOO053) of $B$. dothidea from olive fruit with symptoms of dalmatian disease in Córdoba province was used. In all experiments, noninoculated control fruit were used as controls. Inoculated and control fruit were incubated in humid chambers (plastic containers, 22 by 16 by $10 \mathrm{~cm}$, with $100 \%$ relative humidity [RH]) at $23 \pm 2{ }^{\circ} \mathrm{C}$ under continuous cool fluorescent lights $(350 \mu \mathrm{mol}$ $\mathrm{m}^{-2} \mathrm{~s}^{-1}$ ). Disease severity was assessed at 6 weeks by using a 0 -to5 rating scale (29). There were three replicates (humid chambers) per treatment and 20 fruit per replicate. The full factorial combination (two by two by two) of treatments was arranged in a completely randomized design. Disease severity index (DSI) was calculated in each replication using the following formula: $D S I=\left(\sum n_{i} \times i\right) / N$, where $i$ represents severity (0 to 5), $n_{i}$ is the number of fruit with the severity of $i$, and $N$ is the total number of fruit (29). The experiment was repeated once. Analysis of variance (ANOVA) was performed on the combined DSI data from two experiments. Treatment means of 120 fruit were compared using Tukey's HSD test at $P=0.05$. Data from all experiments were analyzed using Statistix 9.

Pathogenicity on detached fruit. During September 2007, healthy olive fruit of the table cv. Gordal Sevillana were collected from an experimental orchard at Kearney Agriculture Center (KAC) in Parlier, CA. Fruit were washed and disinfested following the procedure developed by Moral et al. (29). Fruit were inoculated individually with each of 11 isolates (Fig. 1), representative of the three Botryosphaeriaceae species studied. Each isolate was inoculated using 10-mm mycelium PDA plugs, which
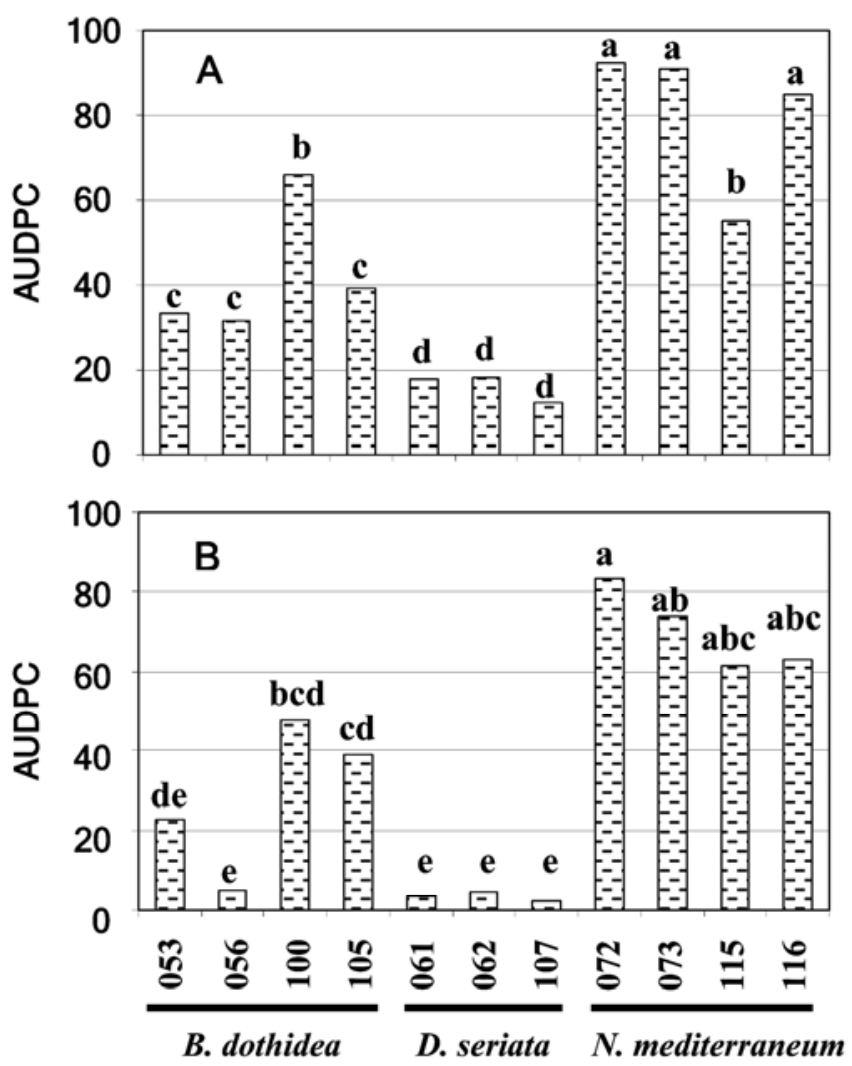

Fig. 1. Disease severity, as determined by the area under disease progress curve (AUDPC), on green olive fruit (cv. Gordal Sevillana) inoculated with Botryosphaeria dothidea, Diplodia seriata, and Neofusicoccum mediterraneum. A, Fruit collected and inoculated during September; B, fruit collected and inoculated during October. For each isolate, mean values with the same letter are not significantly different according to Tukey's honestly significant difference test $(P<0.05)$. were placed in contact with the fruit surface using a sterile pin $(0.2 \mathrm{~mm}$ of diameter) that was pinned superficially $(\approx 1 \mathrm{~mm})$ in the fruit skin. Inoculated and control fruit (PDA plugs without mycelia) were incubated in humid chambers (plastic containers, 40 by 24 by $12 \mathrm{~cm}$, with $100 \% \mathrm{RH}$ ) at room temperature (26 to $\left.33^{\circ} \mathrm{C}\right)$ under continuous cool fluorescent lights $\left(350 \mu \mathrm{mol} \mathrm{m} \mathrm{m}^{-2} \mathrm{~s}^{-1}\right)$. Disease severity was assessed weekly for 1 month by using the 0 to 5 rating scale (29). There were three replicates (humid chambers) per treatment and 30 fruit per replicate. Treatments were arranged in a completely randomized design. A disease index (DI) was calculated as described previously. Area under the disease progress curve (AUDPC) was calculated by trapezoidal integration of DI values over time. ANOVA was performed on the AUDPC data and treatment means were compared using Tukey's HSD test at $P=0.05$. The trial was repeated on fruit collected during October.

Pathogenicity on detached branches. Segments of branches 14 to $18 \mathrm{~cm}$ long and 10 to $15 \mathrm{~mm}$ in diameter were collected from symptomless olive trees of cv. Gordal Sevillana grown at KAC. The branch segments were sealed at both ends with Parafilm (Parafilm, Menasha, WI) to reduce desiccation, and the bark surface was disinfested with ethanol at the inoculation point situated in the middle of each branch. Holes $10 \mathrm{~mm}$ in diameter were made in the bark with a cork borer, just deep enough to remove the outer bark but leave the inner bark intact. A $10-\mathrm{mm}$ diameter mycelium plug of each isolate was placed into each hole and the inoculated area wrapped with Parafilm. Inoculated and control (PDA plugs without mycelia) branches were incubated in humid chambers as described above. Four isolates of $B$. dothidea and four N. mediterraneum isolates (Fig. 2) were tested indi-

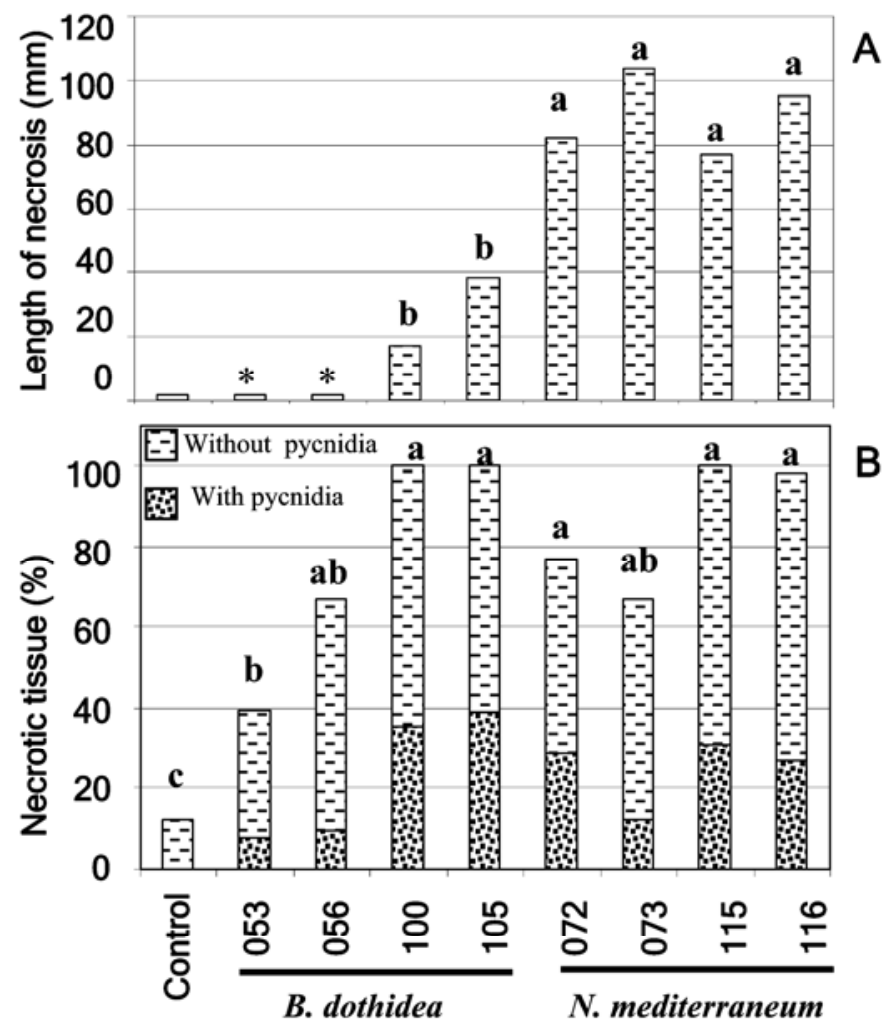

Isolates

Fig. 2. Disease severity 1 month after inoculation with isolates of Botryosphaeria dothidea and Neofusicoccum mediterraneum. A, Length of necrotic tissue $(\mathrm{mm})$ on inoculated branches in the tree; $\mathbf{B}$, percent necrotic tissue (with and without pycnidia) on detached branches. For each isolate, mean values with the same letter are not significantly different according to Kruskal-Wallis test $(P<0.05) ; *$ indicates nonpathogenic isolates. 
vidually, with 10 replicate branches inoculated per isolate. For each branch, lesion length and the length of the colonized bark surface bearing pycnidia were measured after 1 month of incubation. For each of these measurements, the relative (\%) affected length of each branch was calculated. To reisolate the pathogen, two bark chips ( 4 by 4 by $1 \mathrm{~mm}$ ) at 2, 4 , and $6 \mathrm{~cm}$ from the inoculation point of each branch were removed aseptically and cultured on APDA as described above. The experiment was repeated once. The Kruskal-Wallis one-way nonparametric test was performed on the relative length of lesions (\%) and treatment means were compared at $P=0.05$.

Pathogenicity on olive trees. Branches of cv. Gordal Sevillana trees were inoculated in an experimental orchard at KAC during August 2007. Five replicate branches were inoculated per isolate, using the same eight isolates and the method as in the previous experiment. The experiment was performed twice in one olive tree each time. Lesion length and percentage (\%) of dead branches were assessed 3 months after inoculation. The pathogen was reisolated from the olive branches as described above. ANOVA was performed on the lesion length data and treatment means were compared using Tukey's HSD test at $P=0.05$. Data of lesion length in the orchard trials and those in the laboratory trials were compared by Pearson's correlation test.

Effect of temperature on mycelial growth. The effect of temperature on growth and spore germination of Botryosphaeriaceae fungi was studied in detail. A 5-mm-diameter mycelial plug, obtained from actively growing dish cultures of 12 isolates (Table 3), was placed in the center of each petri dish containing PDA. The dishes were incubated in the dark at $5^{\circ} \mathrm{C}$ intervals from 5 to $35^{\circ} \mathrm{C}$ and colony diameter was measured daily for 1 week. Three dishes per isolate were used in this study and the test was conducted twice. Data from both experiments were averaged because a least significant difference (LSD) test showed no significant differences of the mycelial growth between experiments. For each isolate, regression curves were fitted to the values of radial growth (millimeters per day) versus temperature. Three parameters were calculated in the fitted equation for each isolate: optimum temperature $\left({ }^{\circ} \mathrm{C}\right)$ for radial growth, maximum daily radial growth (millimeters per day), and area under the growth curve. The Kruskal-Wallis one-way nonparametric test was performed on the three parameters and isolate means were compared at $P=0.05$.

Effect of temperature on spore germination. A conidial suspension $\left(10^{5}\right.$ conidia $\left./ \mathrm{ml}\right)$ was obtained from pure cultures on PDA of five single-spore $B$. dothidea isolates (BOO079,
BOO080, BOO086, BOO089, and BOO092) mixed at equal amounts. Drops $(5-\mu \mathrm{l})$ of the conidial suspension were placed in the center of a microscope coverslip (20 by $20 \mathrm{~mm}$ ). Four coverslips were placed inside petri dishes containing water agar, which were used as a humid chamber. Dishes were incubated in the dark at $5^{\circ} \mathrm{C}$ intervals from 5 to $50^{\circ} \mathrm{C}$. One coverslip from each temperature treatment was removed after $6,12,24$, and $48 \mathrm{~h}$ of incubation. Spore germination was stopped by staining with acid fuchsin in lactophenol and percent spore germination was determined by observing 50 conidia selected at random on each coverslip. A spore was considered germinated if the germ tube was at least one-half the longitudinal axis of the spore. For each temperature, a mean germination time (MGT) was calculated by the following formula:

$$
M G T=\frac{\sum \Delta G_{i} \times t_{i}}{G_{\max }}
$$

where $\Delta G_{i}$ is the difference in the percentage of germinated spores at each interval $\left(G_{i+1}-G_{i}\right)$ at a given time $(t)$ of incubation, whereby $t_{i}$ is the average number of hours for each time interval $\left[\left(t_{i+1}+t_{i}\right) / 2\right]$ and $G_{\max }$ is the percentage of germinated spores for each temperature at the maximum incubation time of $48 \mathrm{~h}$. The experiment was performed three times and results were averaged because there was no significant difference $(P=0.523)$ among the three experiments in the combined ANOVA. Regression curves were fitted to the values $M G T(\mathrm{~h})$ versus temperature $\left({ }^{\circ} \mathrm{C}\right)$.

Effects of water potential on mycelium growth. To study the ability of $B$. dothidea to grow under dry conditions, the same isolates of the previous experiment were grown on PDA amended with glycerol. The amount of glycerol varied to create different water potential $(\psi)$ levels $(-0.5,-1,-2.5,-5,-10,-15,-20,-25$, and $-30 \mathrm{MPa}$ ) according to Harris (17). Mycelial plugs $(5 \mathrm{~mm}$ in diameter) were taken from the edges of 5-day-old colonies of each isolate and transferred to the center of petri dishes that contained $25 \mathrm{ml}$ of amended PDA. All dishes were sealed with Parafilm and incubated at $25^{\circ} \mathrm{C}$ for 3 days in the dark. Three replicate dishes were used for each $\psi$ level. For each petri dish, colony diameter in millimeters was measured as the mean of two perpendicular diameters. The experiment was repeated once. Because there was no significant difference (LSD test; $P=0.125$ ) between experiments, results were averaged for each isolate. To compare the mycelial growth (millimeters per day) between nonamended PDA and the lowest $\psi(-0.5 \mathrm{MPa})$, a full factorial combination of treatments was arranged in a completely randomized design and treatment means were compared by ANOVA

TABLE 3. Temperature-growth relationship for Botryosphaeriaceae (genera Botryosphaeria, Diplodia, and Neofusicoccum) isolates ${ }^{\mathrm{v}}$

\begin{tabular}{|c|c|c|c|c|c|c|c|c|}
\hline \multirow[b]{2}{*}{ Species } & \multirow[b]{2}{*}{ Isolate } & \multicolumn{4}{|c|}{ Adjusted model $^{\mathrm{w}}$} & \multirow[b]{2}{*}{ Temperature $\left({ }^{\circ} \mathrm{C}\right)^{\mathrm{x}}$} & \multirow[b]{2}{*}{ Growth $(\mathrm{mm} / \text { day })^{\mathrm{y}}$} & \multirow[b]{2}{*}{$\mathrm{AUC}^{\mathrm{z}}$} \\
\hline & & $R^{2}$ & $a$ & $b$ & $c$ & & & \\
\hline Botryosphaeria dothidea & BOO053 & 0.815 & -0.0072 & 0.3173 & -2.0230 & $29.4 \mathrm{ab}$ & $27.2 \mathrm{abc}$ & $513 \mathrm{abc}$ \\
\hline B. dothidea & BOO056 & 0.904 & -0.0068 & 0.2865 & -1.6019 & $28.1 \mathrm{ab}$ & $30.6 \mathrm{a}$ & $576 \mathrm{a}$ \\
\hline B. dothidea & BOO105 & 0.901 & -0.0085 & 0.3820 & -2.7617 & $29.8 \mathrm{a}$ & $30.7 \mathrm{a}$ & $580 \mathrm{a}$ \\
\hline Diplodia seriata & BOO062 & 0.908 & -0.0046 & 0.1920 & -1.0419 & $27.9 \mathrm{ab}$ & $20.8 \mathrm{abc}$ & $392 a b c$ \\
\hline D. seriata & BOO107 & 0.849 & -0.0052 & 0.2062 & -0.7477 & $26.9 \mathrm{~b}$ & $28.8 \mathrm{ab}$ & $559 \mathrm{ab}$ \\
\hline N. mediterraneum & BOF116 & 0.851 & -0.0048 & 0.2012 & -1.1351 & $28.2 \mathrm{ab}$ & $21.1 \mathrm{abc}$ & $398 \mathrm{abc}$ \\
\hline N. mediterraneum & BOP170 & 0.770 & -0.0045 & 0.1847 & -0.9260 & $27.7 \mathrm{ab}$ & $21.3 \mathrm{abc}$ & $408 \mathrm{abc}$ \\
\hline N. mediterraneum & BOP200 & 0.922 & -0.0044 & 0.1934 & -1.2827 & $28.9 \mathrm{ab}$ & $17.1 \mathrm{bc}$ & $322 \mathrm{bc}$ \\
\hline
\end{tabular}

${ }^{\mathrm{v}}$ Data are the average of six replicates for each isolate. For each column, means with the same letter are not significantly different according to Kruskal-Wallis all pairwise comparisons test $(P=0.05)$.

${ }^{\text {w }}$ Mycelial growth on potato dextrose agar at 5 to $35^{\circ} \mathrm{C}$ was adjusted to a third-degree polynomial model: $Y=a \mathrm{~T}^{3}+b \mathrm{~T}^{2}+c \mathrm{~T}$, in which $Y=$ mycelial growth (mm/day); $a, b$, and $c$ are the regression coefficients; and $R^{2}=$ coefficient of determination.

${ }^{x}$ Optimal temperature estimated by the adjusted model.

y Maximum growth rate estimated by the adjusted model.

${ }^{\mathrm{z}}$ Area under the curve of mycelial growth over time. 
using Tukey's HSD test at $P=0.05$. Regression lines were fitted to the values of $\psi$ between -0.5 and $-15 \mathrm{MPa}$ versus mycelial growth rate (millimeters per day) for each isolate. Comparison of slopes and elevations of the regression lines of each isolate was made with Statistix 9, taking into consideration the homogeneity of variances.

\section{RESULTS}

Collection of fungal isolates. In total, 150 Botryosphaeriaceae isolates from rotted olive fruit and branch dieback of olive and other hosts were isolated in Spain and California. Five $B$. dothidea isolates obtained from olive in California produced sexual structures (pseudothecia) on infected olive branches (Table 1). Other fungal pathogens such as Alternaria spp., Colletotrichum acutatum, Fusarium spp., and Phoma glomerata were also isolated from olive fruit. In olive branches, Eutypa lata and Phoma spp. were also isolated, as well as various saprophytic contaminants (Nigrospora, Penicillium, and Epicoccum spp.). However, only the Botryosphaeriaceae fungi were considered for further study. All olive fruit $(n=73)$ with symptoms of dalmatian disease had a wound caused by the olive fly (Bractocera oleae) in the center of the shield lesion. Dalmatian disease was more frequent in the table olive cultivars ( $>2 \%$ fruit incidence) such as Gordal Sevillana, Hojiblanca, and Manzanilla de Sevilla than oil cultivars $(<0.1 \%)$ such as Arbequina or Picual. Olive fruit with typical dalmatian symptoms were not observed in any olive orchards in California.

Morphological characterization. All studied isolates sporulated within 14 days of incubation on olive and pistachio leaves. However, only the Botryosphaeria dothidea and D. seriata isolates sporulated on PDA medium. The medium (PDA or leaves) did not have any effect on the morphology of the conidia. Colonies of $B$. dothidea developing on PDA had abundant fluffy mycelium that was initially gray, becoming olive-gray or gray from the center, with the olive coloration ultimately spreading to the entire colony. Conidia of $B$. dothidea were produced from cylindrical conidiogenous cells and were fusiform, hyaline, and aseptate, measuring (11.8-)20.7-21.6(-27.5) by (3.8-)5.7-6.0(-8.1) $\mu \mathrm{m}$. Isolates from olive fruit with dalmatian disease (BOO053 and BOO056) (Table 1) developed pycnidia on naturally infected olive fruit, which were brown to black and immersed in the fruit tissues, measuring from 100 to $380 \mu \mathrm{m}$ in diameter. These isolates had two kinds of conidia on both synthetic media and olive fruit. The first kind (64\% of conidia) were fusiform, hyaline, and aseptate, with a subacutate apex and a rounded or truncate base, measuring (13.0-)18.6-20.1(-25.0) by (4.0-)5.2-5.7(-7.0) $\mu \mathrm{m}$. The second kind of conidia ( $36 \%$ of conidia) had a smooth, moderately thick, pale brown or, sometimes, hyaline wall. These conidia had 0 to 3 transverse septa, and were subglobose, ellipsoid, or clavate, measuring (10.0-)12.1-13.5(-21.0) by (4.0-)5.27.0(-7.2) $\mu \mathrm{m}$.

Mycelium of $N$. mediterraneum isolates on PDA was not abundant. Initially, mycelium was white, becoming olive-gray or lightly gray. Conidia produced in black pycnidia on pistachio or olive leaves were hyaline, aseptate, and fusiform, and these sometimes showed a truncate base. They developed one or two septa when germinating. $N$. mediterraneum conidia measured (17.00-)21.46-22.63(-25.00) by (4.00-)4.95-5.37(-7.00) $\mu \mathrm{m}$. Isolates of species $N$. parvum had white, abundant mycelium that turned dull whitish-gray as the colony aged. Conidia were hyaline, aseptate, and fusiform or ellipsoid, with an obtuse apex and subtruncate base that measured $(15.8-) 17.0-19.5(-21.8)$ by (4-)5.1-6.2(-8.0) $\mu \mathrm{m}$.

D. seriata isolates formed two different groups according to mycelial characteristics. The first group included isolates from olive and quince fruit collected in Andalusia, whose mycelia were first pastel-gray, becoming olive-gray as the colonies aged. The second group included Californian isolates whose mycelia were abundant, initially whitish-gray, and becoming olive-gray or black as the colonies aged. In both groups, conidia were initially hyaline, becoming dark-brown, aseptate, ovoid, and having an obtuse apex and truncate or rounded base. Conidiogenous cells were hyaline, smooth, and cylindrical, forming two to three annelations. Conidia measured (17.5-)22.5-24.3(-28) by (5.0-)5.7$6.1(-7.0) \mu \mathrm{m}$. The Dichomera synanamorph was not seen in any of the Botryosphaeriaceae species collected.

Molecular characterization. In total, 34 different haplotypes were generated using analyses of DNA sequences of ITS, BT, and EF regions. A partition homogeneity test indicated $(P=0.075)$ that ITS, BT, and EF data set were congruent and could be combined in a single phylogenetic analysis. The entire length of the combined data set (ITS, BT, and EF) was $1,079 \mathrm{bp}$. The AIC criterion as implemented in jModelTest suggested that $\mathrm{TIM}+\mathrm{G}$ was the most appropriate substitution model. Heuristic search under the MP criterion found 160 most-parsimonious trees, with a length of 784 in 1 of the 1,000 replicates. The RI of the best trees was 0.896 , the CI was 0.791, and the HI was 0.209. Considering only the supported nodes, the topologies of ML and strict consensus trees from both MP analyses were fully compatible (data not shown). The ML and MP analyses distinguished two separated clades. The first of the clades was formed by Neofusicoccum and Botryosphaeria species showing bootstrap (BS) support > $40 \%$ and the second by Diplodia and Lasiodiplodia spp. with BS $>90 \%$. Within the first clade, Neofusicoccum and Botryosphaeria species formed two strongly supported subclades with BS values $>90 \%$ (Fig. 3). The 18 sequenced N. mediterraneum isolates led to six different haplotypes. The five $N$. parvum isolates from Spain showed identical sequences and were close to $N$. ribis reference isolates, with BS values of $99 \%$. Botryosphaeria species formed a homogeneous subclade, which was characterized by almost no variation within it. Diplodia spp. grouped together in a subclade that was strongly supported by the BS value $>90 \%$. The eight $D$. seriata isolates yielded two different haplotypes corresponding with those isolated from Spain and California. This geographical relationship was supported by high BS values (>90\%) (Fig. 3).

When the ITS and EF sequence data of olive isolates were combined, the four haplotypes, from the 10 sequenced $N$. mediterraneum isolates, showed scant genetic variation among them (four variable positions). These isolates formed a group close to $N$. viticlavatum and $N$. vitifusiforme sequences. The eight $B$. dothidea haplotypes also showed low variation (13 variable positions) among them. In fact, the three haplotypes yielded by the $26 \mathrm{~B}$. dothidea isolates differed only in positions considered as gaps. The haplotypes that clustered with $D$. seriata from olive belonged to two subgroups. The first of these represents four isolates affecting olive and quince fruit in Andalusia and the second $D$. seriata isolates causing dieback of branches in California. This division was supported by seven variable positions fixed between both $D$. seriata subgroups (Supplemental Figures).

Pathogenicity tests. Effects of cultivar, wounding, and inoculation method. Necrotic lesions were observed at 4 weeks after inoculation with a conidial suspension on the wounded fruit of cv. Manzanilla de Sevilla. In general, the symptoms progressed until the entire surface of all the fruit was covered. None of the inoculated fruit developed typical dalmatian disease symptoms. Cultivar, wounding, and inoculation method had a significant effect on DSI but their interactions were not significant $(P=$ 0.346). The cv. Manzanilla de Sevilla was more severely affected by $B$. dothidea than $\mathrm{cv}$. Hojiblanca $(P=0.0001)$. Wounding was not needed for infection and symptom development. Nevertheless, symptoms were more severe on wounded fruit than unwounded fruit $(P=0.0169)$. Fruit inoculated with a conidial suspension developed more severe symptoms than those inoculated using a mycelial plug $(P=0.0097)$ (Fig. 4). 
Pathogenicity on detached fruit. When unripe olive fruit were inoculated using a mycelial plug, the first symptom was a small necrotic lesion surrounding the inoculation point, which advanced until it covered the entire surface of the fruit. When the fruit were inoculated during September 2007, there were significant $(P<$ $0.0001)$ differences among isolates. Isolates of $N$. mediterraneum were the most aggressive and those of $D$. seriata the least aggressive (Fig. 1A). In this trial, all Botryosphaeriaceae isolates, except D. seriata isolates BOO061 and BO0062, developed pycnidia on the fruit surface 21 days after inoculation. Three of the four $B$. dothidea isolates developed typical dalmatian disease symptoms but only on $3.3 \%$ of fruit. Inoculations of fruit during October gave similar results (Fig. 1B). However, in this case, none of the inoculated fruit developed symptoms of dalmatian disease.

Pathogenicity on detached branches. All the Botryosphaeriaceae isolates produced a black necrotic lesion with pycnidia 4 weeks after inoculation of the olive branches (Fig. 2A). Percentage of branch tissue exhibiting disease symptoms was significantly different $(P<0.0001)$ among isolates. $B$. dothidea isolates from olive fruit with dalmatian disease produced substantially smaller lesions than those caused by the remaining Botryosphaeriaceae isolates from olive and ash branches.

Pathogenicity on olive trees. When olive branches were inoculated under field conditions, the first symptoms (vascular discoloration) were observed 2 weeks after inoculation. In this trial, $N$. mediterraneum isolates were more aggressive than $B$. dothidea isolates from olive branches (Fig. 2B). In addition, $23 \%$ of branches inoculated with $N$. mediterraneum developed cankers and, eventually, dieback. B. dothidea isolates from olive fruit were not pathogenic (Fig. 2B). The pathogenic fungi were reisolated from all symptomatic branches. For isolates causing disease, there was a significant correlation (Pearson's; $r=0.8494$; $P=0.038$ ) between the length of vascular discoloration resulting from inoculations on detached branches in the laboratory and inoculations under field conditions.

Effect of temperature on mycelial growth. All isolates studied grew on PDA at 10 to $30^{\circ} \mathrm{C}$ but some of the isolates failed to grow at 5 or $35^{\circ} \mathrm{C}$. Optimal temperature for mycelial growth was 26.9 to $29.8^{\circ} \mathrm{C}$. Significant differences were found in the optimal temperature of isolates BOO105 and BOO072 $(P<$ 0.0001 ) but there was extensive overlap for the optimal temperature of the remaining isolates that could not be differentiated statistically (Table 3). The Kruskal-Wallis test also indicated that maximum growth rates of isolates differed significantly $(P<$ 0.0001). For all isolates, the relationship between growth rate (millimeters per day) and temperature was best described by a third-degree polynomial $\left(Y=a \mathrm{~T}^{3}+b \mathrm{~T}^{2}+c \mathrm{~T}\right)$. In all cases, the three regression coefficients were highly significant $(P<0.0001)$ and the coefficient of determination $\left(R^{2}\right)$ was 0.770 to 0.922 . In general, isolates were separated in two groups: $B$. dothidea (four isolates) and $D$. seriata isolate BOO107, whose maximum growth rate was $>27 \mathrm{~mm} /$ day; and a second group comprising $D$. seriata (isolate BOO062) and N. mediterraneum (five isolates), whose maximum growth rate was $<22 \mathrm{~mm} /$ day. This separation into two groups was also observed when the area under the curve (AUC) of mycelial growth over time was calculated (Table 3 ).

Effect of temperature on spore germination. The two kinds of conidia of $B$. dothidea isolates from olive with typical dalmatian disease symptoms germinated, developing one to two germ tubes. Germination occurred when conidia were incubated at 5 to $40^{\circ} \mathrm{C}$. Conidial germination began $6 \mathrm{~h}$ after the conidia were placed in the humid chambers and when temperatures were $>5^{\circ} \mathrm{C}$ (Fig. 5A). Morphology of germ tubes was similar at all

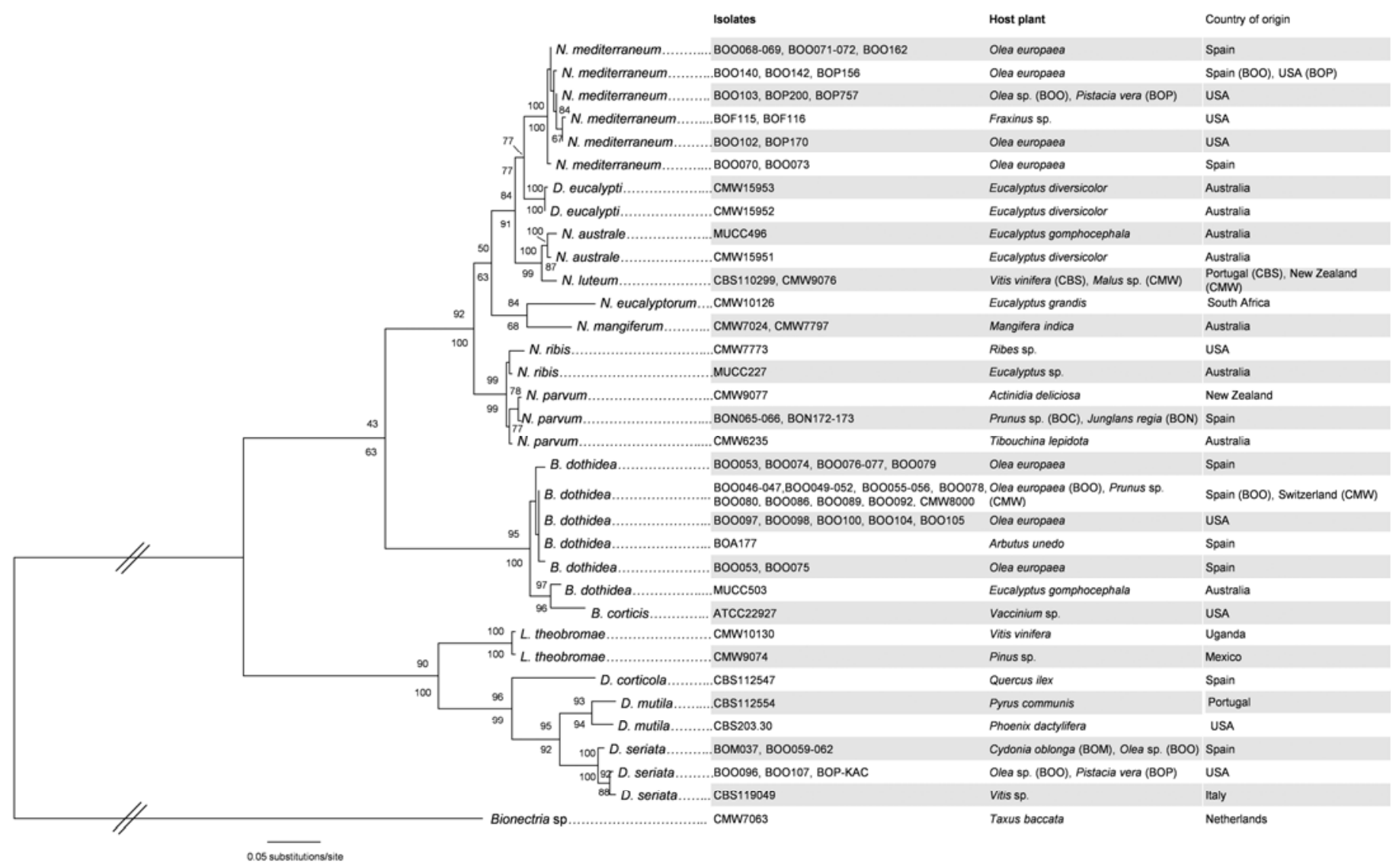

Fig. 3. Phylogenetic tree of Botryosphaeriaceae (Botryosphaeria, Dichomera, Diplodia, Lasiodiplodia, and Neofusicoccum) species. Maximum likelihood (ML) phylogram inferred with PHYML from the internal transcribed spacers + $\beta$-tubulin + elongation factor haplotypes combined dataset. Branch lengths are scaled in terms of the expected number of substitutions per site. Numbers above branches represent ML bootstrap values and below branches represent maximum parsimony bootstrap values. The right side of the diagram indicates the isolate, host plant, and country of origin for each haplotype. 
temperatures tested. Although maximum germination occurred for all temperatures after $48 \mathrm{~h}$ of incubation, the percent germination and MGT varied greatly with temperature. The optimal temperature for germination was $30^{\circ} \mathrm{C}$. The best regression model for MGT (h) and temperature $\left({ }^{\circ} \mathrm{C}\right)$ was a second-degree polynomial model. In this model, the minimum MGT was $5.15 \mathrm{~h}$ at the optimum temperature $\left(23.2^{\circ} \mathrm{C}\right)$. However, the MGT was very similar for temperatures between 20 and $30^{\circ} \mathrm{C}$ (Fig. 5B).

Effects of water potential on mycelium growth. After incubation at $25^{\circ} \mathrm{C}$ for 3 days, the five isolates of $B$. dothidea from olive fruit grew significantly $(P=0.0035)$ more at -0.5 than $0 \mathrm{MPa}$ (control medium, PDA). The radial growth rate of all the isolates declined linearly $\left(P<0.001 ; R^{2}=0.964 ; R a^{2}=0.959\right)$ as $\psi$ decreased from -0.5 to $-15 \mathrm{MPa}$ (data not shown). The comparison among the linear regression lines of each isolates for $\psi$ from -0.5 to $-15 \mathrm{MPa}$ showed equality of variances $(P=0.936)$, with no significant differences between slopes $(P=0.586)$ and elevations $(P=0.339)$. None of the tested isolates grew at osmotic potential $\geq-15 \mathrm{MPa}$.

\section{DISCUSSION}

We recorded four different species from olive and other hosts from Spain and California: N. mediterraneum, B. dothidea, D. seriata, and $N$. parvum. The three first species were isolated from olive and other hosts while $N$. parvum was not isolated from olive but only from branches of walnut. In Spain, only $B$. dothidea causes dalmatian disease of olive fruit; $N$. mediterraneum infects branches of the same host and causes shoot cankers and dieback; and $D$. seriata causes fruit rot of olive, which develops later in the season than that from infection by $B$. dothidea. The same three species were isolated from California olive but only from shoot cankers or blighted shoots. The four species isolated were identified using a combination of morphological (conidial) and molecular (ITS, EF, and BT sequence) characters. Infection of agricultural or forest trees by several species of Botryosphaeriaceae have been previously described $(5,28,39,41,43)$. This study is the first report of $N$. mediterraneum from olive and pistachio and $N$.

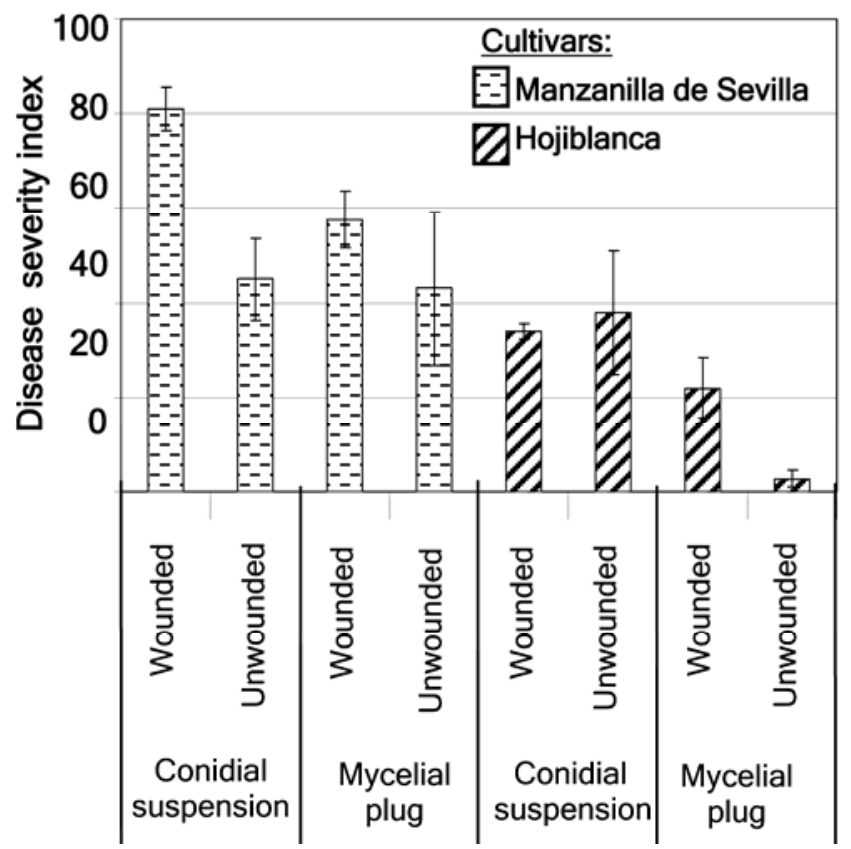

Fig. 4. Effect of olive cultivar, inoculation method, and wounding on disease severity index in olive fruit inoculated with an isolate of Botryosphaeria dothidea from olive fruit with typical dalmatian disease symptoms. Bars represent the average of 120 fruit. Vertical lines represent the standard errors of the means. parvum from walnut and plum in Spain. The species $N$. mediterraneum has been described for the first time attacking olive and ash in California. Moreover, the species B. dothidea was reported for the first time infecting branches of the strawberry tree.

$B$. dothidea was isolated from all the fruit showing symptoms of dalmatian disease in Spain. Lazzizera et al. (22) reported $B$. dothidea to be the most important species associated with rotted fruit of olive in Italy. However, these researchers did not describe the specific symptoms on diseased fruit. In our study, the isolates from dalmatian disease formed two types of conidia. Morphology and dimensions of both kinds of conidia and the phylogenetic analysis correlated well with the $B$. dothidea from olive fruit in Greece described by Phillips et al. (33). The Spanish and Greek isolates did not show conidia with longitudinal septa. In contrast, Zachos and Tzavella-Klonari (52) observed that isolates from dalmatian disease showed longitudinal septa in the ovoid conidia. On the basis of this morphological characteristic, they reclassified the fungus as Camarasporium dalmaticum. However, this description could correspond to the Dichomera synanamorph described by Barber et al. for Botryosphaeria species isolated from Eucalyptus spp. (3). In our study, D. seriata was isolated from infected ripe olive fruit. In Italy, four species of Diplodia have been associated with rotted olive fruit, with $D$. seriata being the most common (21). Moreover, the Spanish isolates causing dieback of olive branches were identified as $N$. mediterraneum, whereas the same fungus was previously identified by only morphological characteristics as $N$. ribis, due to the fact that these species are closely related (37).

The ITS, BT, and EF combined sequences provided information on the inter- and intrageneric relationships among all the Botryosphaeriaceae species studied while the ITS and EF combined phylogenetic analysis was successful to describe the diversity of the species that affect olive trees in Spain, California,
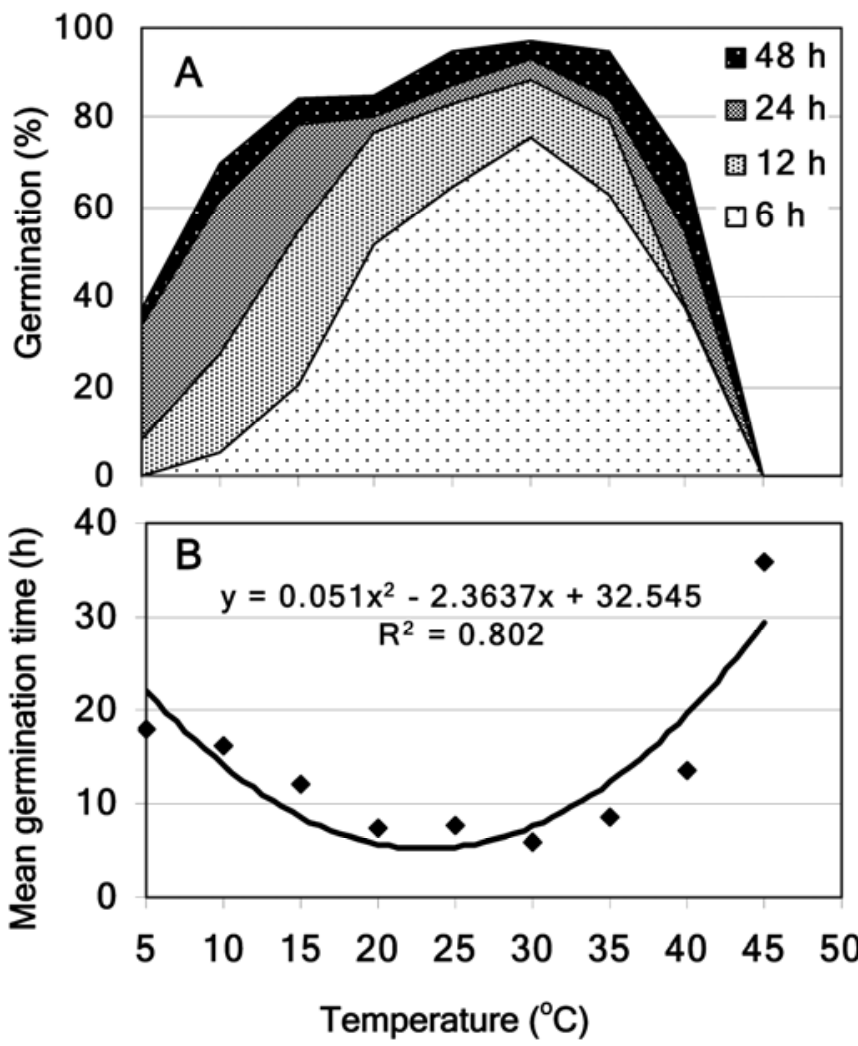

Fig. 5. Effect of temperature and incubation time on germination of a conidial suspension mixture of five Botryosphaeria dothidea isolates from olive fruit with typical dalmatian disease symptoms. A, Percent germinated conidia after $6,12,24$, and $48 \mathrm{~h}$ of incubation; $\mathbf{B}$, relationship between mean germination time and temperature. 
Greece, and Italy $(22,33)$. The phylogenetic analysis confirmed previous studies placing the Botryosphaeriaceae species in three genera, such as Botryosphaeria, Diplodia, and Neofusicoccum $(22,43,48)$. Isolates of $B$. dothidea and $B$. corticis were also grouped together as reported by Crous et al. (9). However, the results indicate that the reference isolate MUCC503, which was previously described as $B$. dothidea, is more closely related to $B$. corticis rather than to $B$. dothidea. The isolates from different geographical origins and hosts showed low intraspecific variation, although $D$. seriata isolates from the United States had fixed nucleotide changes when compared with the Spanish isolates. The Californian D. seriata isolates were not arranged in a defined group with respect to isolates from other origins (32) but these fixed changes could suggest a speciation process produced by geographical isolation. However, the divergence level and the number of isolates studied of both Diplodia subgroups were too low to confirm this hypothesis. When only olive isolates from different countries were studied, isolates of Diplodia and Neofusicoccum showed lower variation than that of $B$. dothidea; although this low variation could be due partially to the small number of isolates sequenced or to higher levels of variability associated with the sexual reproduction of $B$. dothidea (28).

The purpose of collecting isolates of Botryosphaeriaceae from hosts other than olive but growing near olive trees was to determine whether these hosts share the same Botryosphaeriaceae pathogens. For instance, pistachio suffers from a severe Botryosphaeria panicle and shoot blight and olive from a less severe shoot blight. These crops sometimes are grown next to each other or in proximity of 0.1 to $0.5 \mathrm{~km}$. Frequently, olive and pistachio grow together in the same orchard in Spain. In addition, in northern California, olive trees are planted along road sides separating pistachio, almond, and walnut groves, or in orchards on their own. Moreover, the molecular analyses data of this study showed that most of the isolates of Botryosphaeriaceae from other hosts were identical to the isolates obtained from olive. Similarly, Ma and Michailides (24) showed that the isolates of Botryosphaeriaceae from pistachio and other hosts shared identical Botryosphaeriaceae pathogens that caused blights on various tree species throughout California. Ma et al. (23) also showed that the haplotypic variation was the lowest on pistachio, where no perithecial stage was found when compared with isolates from six other tree species.

The pathogenicity tests showed that $N$. mediterraneum was significantly more aggressive on olive fruit than dalmatian disease isolates of $B$. dothidea tested. However, this species has not been found to cause dalmatian disease under field conditions in Spain or California, and is uncommon in Italy (22). Isolates of $B$. dothidea from olive fruit with symptoms of dalmatian disease were weakly aggressive on fruit and not pathogenic on branches. These results suggest that there is some unique preference of each of these species in respect to the olive tissues they infect. $D$. seriata was also weakly aggressive on unripe olive fruit. This is in agreement to Moral et al. (30), who reported that D. seriata infected ripe olive fruit during the winter. Among the three Botryosphaeriaceae species tested, the least aggressive was $D$. seriata, perhaps explaining partially why this species is not as common on olive as the other two species. Similarly, B. dothidea isolates were more aggressive than $D$. seriata isolates when inoculated on fruit, trunks, and twigs of apple trees (5). The crossinfection potential of $N$. mediterraneum between olive and pistachio in Spain and California suggest that sources of inoculum for olive infection by these pathogens can come from other proximal hosts and vice versa. Likewise, $D$. seriata causing black rot of quince fruit can infect olive and vice versa, because these two crops are cultivated in the same geographic region (Andalusia, southern Spain).

Apparently, the use of conidial suspension represents a natural method of fruit inoculation because conidia of Botryosphaeria species need water to exude from pycnidia, spread, and be deposited on host tissues. Similarly, inoculation of olive fruit with a conidial suspension of $B$. dothidea resulted in more severe disease than inoculation with a mycelial plug. Michailides and Morgan (28) and Ahimera et al. (2), in their work with panicle and shoot blight of pistachio (caused by a member of the family Botryosphaeriaceae), showed the effects of sprinkler irrigation and rain on the spread of conidia. In the trials reported here, wounding was not necessary for infection of olive fruit but the severity of symptoms was enhanced when fruit were wounded. These results do not agree with previous studies, where wounding was necessary for fruit infection by the isolates that caused dalmatian disease $(14,52)$. Only isolates of $B$. dothidea caused the typical "escudete" on the inoculated fruit, but only on $3.3 \%$ of the inoculated fruit. The small percentage of fruit with "escudete" may have been due to the high humidity in the inoculation chambers, a condition that is very different from the natural conditions encountered during summer and fall in Spain, when dalmatian disease usually develops.

A high incidence of Botryosphaeriaceae species in pruning wounds has been reported on different crop trees (28) from which they can establish themselves in the wood. In this study, two specific $N$. mediterraneum isolates were isolated from cankers on olive branches of $3 \mathrm{~cm}$ in diameter surrounding pruning wounds. The mechanical harvest system that has been newly implemented in Spanish olive groves and is increasing in California groves is expected to create more wounds on shoots and branches of the trees and may result in greater risk for infection by Botryosphaeriaceae species and other wound-associated pathogens.

The close association between the typical dalmatian disease symptom and the wound created by the olive fly in this study is of interest. In previous studies, however, the incidence of dalmatian disease was associated with the cecydomiid Prolasioptera berlesiana, whose larva feed on eggs of the olive fly (18). In Spain, a high percentage $(77.5 \%)$ of olive fruit affected by dalmatian disease did not bear larvae of this cecydomiid insect (16), suggesting that the olive fly may facilitate the infection of fruit by directly wounding the fruit during oviposition. The absence of the olive fly in California until recently could partially explain the absence of dalmatian disease in the United States (36), although cultivars similar to those cultivated in Spain are commercially grown. Also in California, a similar association with insects was reported for infection of pistachio fruit by $B$. dothidea and punctures made by large hemipteran insects (28). In Greece, Chitzanidis (8) reported that infections of pistachio fruit (cv. Aegina) started through wounds made by larvae of Palumbina guerinii, a Thysanoptera insect pest.

Dalmatian disease usually starts in the middle of summer under high temperatures and dry conditions in southern Spain $(4,16,27)$. Physiological characterization of isolates causing dalmatian disease demonstrated that the optimum temperature was $26^{\circ} \mathrm{C}$ for growth of mycelium and $30^{\circ} \mathrm{C}$ for germination of conidia. Zachos and Tzavella-Klonari (53), working with isolates causing dalmatian disease on Greek olive, described a linear model for mycelial growth of 10 to $30^{\circ} \mathrm{C}$, with a sharp decline at $35^{\circ} \mathrm{C}$. On the other hand, their reported mean germination time $(\approx 7 \mathrm{~h})$ of conidia was similar to that determined in this study at temperatures of 20 to $35^{\circ} \mathrm{C}$. These results imply that the fungus has the potential to grow under high temperatures, which are typical during olive fruit development in summer and early fall. In this study, isolates of $B$. dothidea had a maximum growth rate higher than that of $N$. mediterraneum and $D$. seriata. The greater adaptation of $B$. dothidea to higher temperatures could provide another explanation of its prevalence in causing dalmatian disease, and the absence of $N$. mediterraneum, which had higher aggressiveness on olive branches.

The range of $\psi$ in the medium for growth of $B$. dothidea was 0 to $-10 \mathrm{MPa}$, similar to that required by most fungi (17), sug- 
gesting that $B$. dothidea is not particularly adapted to low humidity, probably getting its water requirements by growing inside the olive fruit. Similar results were observed by Zachos and Tzavella-Klonari (53) working with isolates of dalmatian disease pathogen in Greece. However, when Ma et al. (25) imposed drought stress on potted pistachio trees, which were inoculated with $B$. dothidea, the trees developed more severe disease symptoms than the normally irrigated trees. California and Andalusia regions have suffered severe drought in the last several years and diseases caused by species of Botryosphaeriaceae in olive and various other crops seem to have become more common. This was confirmed by the ease of collecting a large number of Botryosphaeriaceae isolates from the blighted branches of olive and other host trees growing in the proximity of olive trees and along roads and borders of farms. Similarly, dieback of olive branches of cv. Gordal Sevillana has increased during the last dry years in southern Spain.

A number of significant findings were discovered through this study, with a large number of isolates of Botryosphaeriaceae collected from olive and other hosts from two countries. Three species are involved in causing serious diseases of olive, with $B$. dothidea causing dalmatian disease of unripe olive fruit in Spain, $N$. mediterraneum causing branch blights in olive and pistachio in Spain and California, and D. seriata causing branch canker in California and branch canker and rot of ripe olive fruit in Spain. The variation found between Botryosphaeriaceae species causing fruit rot or branch canker of olive should be taken into account for different control strategies depending on the species involved. Because of aggressiveness, the pathogen having the highest risk for olive trees in Spain and California is N. mediterraneum; therefore, specific control measures need to be developed, particularly when highly susceptible cultivars such as Gordal Sevillana are grown. Finally, an early harvest may be a good measure to escape from fruit rot caused by $D$. seriata.

\section{ACKNOWLEDGMENTS}

This research was funded by project CA-D*-PPA-6628-H (T. J. Michailides) and project P08-AGR-03635 of the Andalusia Regional Government (A. Trapero). We thank the Spanish Ministry of Education and Science (project AGL2004-7495) for granting J. Moral a stay at the University of California-Davis and Kearney Agricultural Center for 5 months, F. Luque and G. Karaoglanidis for their skillful technical assistance with inoculation trials, P. Inderbitzin and M. Yaghmour for their assistance in the laboratory, D. Morgan for reviewing this manuscript, and E. Barrio for his support in the phylogenetic analysis.

\section{LITERATURE CITED}

1. Aa, H. A. Van Der, and Vanev, S. 2002. A Revision of the Species Described in Phyllosticta. CBS, Utrecht, The Netherlands.

2. Ahimera, N., Gisler, S., Morgan, D. P., and Michailides, T. J. 2004. Effects of single-drop impactions and natural and simulated rains on the dispersal of Botryosphaeria dothidea conidia. Phytopathology 94:11891197.

3. Barber, P. A., Burgess, T. I., Keane, P. J., Hardy, G. E. S. J., Slippers, B., and Wingfield, M. J. 2005. Botryosphaeria species from Eucalyptus in Australia are pleoanamorphic, producing Dichomera synanamorphs in culture. Mycol. Res. 109:1347-1363.

4. Barranco, D., Fernández-Escobar, R., and Rallo, L., eds. 2008. El cultivo de olivo. Junta de Andalucía \& Mundi-Prensa, Madrid.

5. Brown-Rytlewski, D. E., and McManus, P. S. 2000. Virulence of Botryosphaeria dothidea and Botryosphaeria obtusa on apple and management of stem cankers with fungicides. Plant Dis. 84:1031-1037.

6. Butin, H. 1993. Morphological adaptation and spore pleomorphism in the form-complex Dichomera-Camarosporium and Fusicoccum-Dothiorella. Sydowia 45:161-166.

7. Carbone, I., Anderson, J. B., and Kohn, L. M. 1999. A method for designing primer sets for the speciation studies in filamentous ascomycetes. Mycologia 91:553-556.

8. Chitzanidis, A. 1994. Pistachio diseases in Greece. Acta Hortic. 419:345348.
9. Crous, P. W., Slippers, B., Wingfield, M. J., Rheeder, J., Marasas, W. F. O., Phillips, A. J. L., Alves, A., Burgess, T., Barber, P., and Groenewald, J. Z. 2006. Phylogenetic lineages in the Botryosphaeriaceae. Stud. Mycol. 55:235-253

10. del Moral, J., Mazón, J. J., and Santiago, R. 1986. Phlyctema vagabunda Desm. y Arx y Fusarium moniliforme Sheidon, nuevos patógenos de la aceituna en España. Bol. San. Veg. Plagas 12:9-17.

11. Felsenstein, J. 1981. Evolutionary trees from DNA sequences: a maximum likelihood approach. J. Mol. Evol. 17:368-376.

12. Felsenstein, J. 1985. Confidence limits on phylogenies: an approach using the bootstrap. Evolution 39:783-791.

13. García, M. D. 2007. Repercusiones sociales y económicas del sector de la aceituna de mesa. Grasas Aceites (Seville) 58:56-63.

14. Gigante, R. 1934. Ricerche sulla morfología, la biologia e la posizione sistematica del fungo che é stato descritto come Macrophoma dalmatica. Boll. Regia Stn. Patol. Veg. N. S. 14:125-172.

15. Glass, N., and Donaldson, G. C. 1995. Development of primer sets designed for use with the PCR to amplify conserved genes from filamentous Ascomycetes. Appl. Environ. Microbiol. 61:1323-1330.

16. González, N. 2005. Aspectos biológicos y epidemiológicos del Escudete de la aceituna causado por Camarosporium dalmaticum. Tesis de Master of Science en Olivicultura y Elaiotecnia. ETSIAM, Universidad de Córdoba, Córdoba, Spain.

17. Harris, R. F. 1981. Effect of water potential on microbial growth and activity. Pages 23-95 in: Water Potential Relations in Soil Microbiology. J. F. Parr, W. R. Gardner, and L. F. Elliot, eds. Soil Science Society of America, Madison, WI.

18. Iannotta, N., Noce, M. E., Ripa, V., Scalercio, S., and Vizzarri, V. 2007. Assessment of susceptibility of olive cultivars to the Bactrocera oleae (Gmelin, 1790) and Camarosporium dalmaticum (Thüm) Zachos \& Tzav.-Klon. attacks in Calabria (Southern Italy). J. Environ. Sci. Health 42:789-793.

19. Jacobs, K. A., and Rehner, S. A. 1998. Comparisons of cultural and morphological characters and ITS sequences in anamorphs of Botryosphaeria and related taxa. Mycologia 90:601-610.

20. Kornerup, A., and Wanscher, J. H. 1963. Methuen Handbook of Colour. Methuen and Co. Ltd., London.

21. Lazzizera, C., Frisullo, S., Alves, A., Lopes, J., and Phillips, A. J. L. 2008. Phylogeny and morphology of Diplodia species on olives in Italy and description of Diplodia olivarum sp. nov. Fungal Divers. 37:63-71.

22. Lazzizera, C., Frisullo, S., Alves, A., and Phillips, A. J. L. 2008. Morphology, phylogeny and pathogenicity of Botryosphaeria and Neofusicoccum species associated with drupe rot of olive in southern Italy. Plant Pathol. 57:948-956.

23. Ma, Z., Boehm, E. W. A., Luo, Y., and Michailides, T. J. 2001. Population structure of Botryosphaeria dothidea from pistachio and other hosts in California. Phytopathology 91:665-672.

24. Ma, Z., and Michailides, T. J. 2002. Characterization of Botryosphaeria dothidea isolates collected from pistachio and other plant hosts in California. Phytopathology 92:519-526.

25. Ma, Z., Morgan, D. P., and Michailides, T. J. 2001. Effects of water stress on Botryosphaeria blight of pistachio caused by Botryosphaeria dothidea. Plant Dis. 85:745-749.

26. M.A.P.A. 2006. Boletín mensual de estadística. Ministerio de Agricultura Pesca y Alimentación, Madrid.

27. Mateo-Sagasta, E. 1968. Notas sobre un nuevo tipo de ataque criptogámico en aceitunas españolas posiblemente atribuible a una nueva forma de ataque del hongo Macrophoma dalmatica. Bol. Patol. Veg. Entomol. Agric. 30:137-146.

28. Michailides, T. J., and Morgan, D. P. 2004. Panicle and shoot blight of Pistachio: A major threat to the California pistachio industry. APSnet Feature. Published online by The American Phytopathological Society, St. Paul, MN.

29. Moral, J., Bouhmidi, K., and Trapero, A. 2008. Influence of fruit maturity, cultivar susceptibility, and inoculation method on infection of olive fruit by Colletotrichum acutatum. Plant Dis. 92:1421-1426.

30. Moral, J., Luque, F., and Trapero, A. 2007. First report of Diplodia seriata, the anamorph of "Botryosphaeria" obtusa, causing fruit rot of olive in Spain. Plant Dis. 92:311.

31. Moral, J., Muñoz-Díez, C., González, N., Michailides, T. J., and Trapero, A. 2008. Genetic, morphological, and pathogenic diversity of Botryosphaeriaceae species from olive in Spain and California. Page 57 in: Abstracts of VI International Symposium on Olive Growing. Evora, Portugal.

32. Phillips, A. J. L., Crous, P., and Alves, A. 2007. Diplodia seriata the anamorph of "Botryosphaeria" obtusa. Fungal Divers. 25:141-155.

33. Phillips, A. J. L., Rumbos, I. C., Alves, A., and Correia, A. 2005. Morphology and phylogeny of Botryosphaeria dothidea causing fruit rot of olives. Mycopathologia 159:433-439.

34. Posada, D. 2008. jModelTest: Phylogenetic model averaging. Mol. Biol. Evol. 25:1253-1256. 
35. Posada, D., and Buckley, T. R. 2004. Model selection and model averaging in phylogenetics: Advantages of akaike information criterion and bayesian approaches over likelihood ratio tests. Syst. Biol. 53:793808.

36. Rice, R. E., Phillips, P. A., Stewart-Leslie, J., and Sibbett, G. S. 2006. Olive fruit fly populations measured in Central and Southern California. Calif. Agric. 57:122-127.

37. Romero, M. A, Sánchez, M. E., and Trapero, A. 2005. First report of Botryosphaeria ribis as a branch dieback pathogen of olive trees in Spain. Plant Dis. 89:208.

38. Rozas, J. 2009. DNA sequence polymorphism analysis using DnaSP. Methods Mol. Biol. 537:337-350.

39. Sánchez, M. E., Venegas, J., Romero, M. A., Phillips, A. J. L., and Trapero, A. 2003. Botryosphaeria and related taxa causing oak canker in southwestern Spain. Plant Dis. 87:1515-1521.

40. Schroth, M. N., and Osgood, J. W. 1971. Relationship between the olive knot disease and reduced yield. Calif. Olive Ind. News 25, no. 1 (February).

41. Slippers, B, Crous, P. W., Denman, S., Coutinho, T. A., Wingfield, B. D., and Wingfield, M. J. 2004. Combined multiple gene genealogies and phenotypic characters differentiate several species previously identified as Botryosphaeria dothidea. Mycologia 96:83-101.

42. Slippers, B., Fourier, G., Crous, P. W., Counthinho, T. A., Wingfield, B. D., Carnegie, A., and Wingfield, M. J. 2004. Speciation and distribution of Botryosphaeria spp. on native and introduced eucalyptus trees in Australia and South Africa. Stud. Mycol. 50:343-358.

43. Slippers, B., Smith, W. A., Crous, P. W., Counthinho, T. A., Wingfield, B. D., and Wingfield, M. J. 2007. Taxonomy, phylogeny and identification of Botryosphaeriaceae associated with pome and stone fruit trees in South Africa and other regions of the world. Plant Pathol. 56:128-139.

44. Smith, D. R., Michailides, T. J., and Stanosz, G. R. 2001. Differentiation of a Fusicoccum species causing panicle and shoot blight on California pistachio trees from Botryosphaeria dothidea. Plant Dis. 85:1235-1240.

45. Tamura, K., Dudley, J., Nei, M., and Kumaro, S. 2007. MEGA4: Molecular evolution genetics analysis. Mol. Biol. Evol. 24:1596-1599.

46. Teviotdale, P. 2005. Diseases of olive. Pages 107-109. in: Olive Production Manual. G. S. Sibbett, L. Ferguson, J. L., Coviello, and M. Lindstrand, eds. University of California Agriculture and Natural Resources, Oakland.

47. Thümen, F. 1883. Die Pilze des Oelbaumes. Boll. Soc. Adriat. Sci. Trieste 8:215-244

48. Úrbez-Torres, J. R., Leavitt, G. M., Voegel, T., and Gubler, W. D. 2006. Identification and distribution of Botryosphaeria species associated with grapevine cankers in California. Plant Dis. 90:1490-1503.

49. Vossen, P. 2007. Olive oil: history, production, and characteristics of the world's classic oils. HortScience 42:1093-1100.

50. White, T. J., Bruns, T., Lee, S., and Taylor, J. 1990. Amplification and direct sequencing of fungi ribosomal RNA genes for phylogenetics. Pages 315-322 in: PCR Protocols. A Guide to Methods and Applications. M. A. Innis, D. H. Gelfand, J. J. Sninsky, and T. J. White, eds. Academic Press, San Diego, CA.

51. Wilgenbusch, J. C., and Swofford, D. 2003. Inferring evolutionary trees with PAUP. Pages 1-28 in: Current Protocols in Bioinformatics. A. D. Baxevanis, D. B. Davison, R. D. M. Page, G. A. Petsko, L. D. Stein, and G. D. Stormo, eds. Wiley and Sons, New York.

52. Zachos, D. G., and Tzavella-Klonari, K. 1979. Recherches sur l'identité et la position systématique du champignon qui provoque la maladie de olives attribuée au champignon Macrophoma o Sphaeropsis dalmatica. Ann. Inst. Phytopathol. Benaki 12:9-71.

53. Zachos, D. G., and Tzavella-Klonari, K. 1983. Recherches sur les causes des infections localisées ou géneéralisées des olives attaquées par le champignon Camarosporium dalmatica. I. Influence de 1'humidité, de la pression osmotique et du $\mathrm{pH}$ des fruits. Ann. Inst. Phytopathol. Benaki $14: 1-9$. 